\title{
Menakar Ulang Hermeneutika dalam Studi Alquran di Era Modern dan Kontemporer (Pendekatan Sastra, Sejarah dan Sains)
}

\section{Darsitun}

Program Doktor Pendidikan Islam IAIN Purwokerto, Email: masdar1982@gmail.com

\begin{abstract}
Abstrak
Penulisan artikel ini dilatarbelakangi fenomena kembang kempisnya elaborasi pemikiran seputar penafsiran Alquran pada zaman modern dan kontemporer seperti sekarang. Metode penulisan artikel dengan menggunakan jenis pendekatan library research melalui pendekatan analisis deskriptif. Hasil dari penelitian ini menunjukkan titik tengah jalan temu sebagai sikap moderat dalam menyikap fenomena penggunakan Hermeneutika dalam penafisran Alquran. adakalanya pemahaman Hermeneutikan ini digunakan dengan tetap memperhatikan adab-adab terhadap kesakralan Alquran dan adakalanya tidak digunakan sama sekali pada wilayah-wilayah diluar jangkauan akal manusia.
\end{abstract}

Kata kunci : Hermeneutika; Penafsiran; Keagungan Alquran

\begin{abstract}
The writing of this article is motivated by the phenomenon of the development of the elaboration of thought about the interpretation of the Qur'an in modern and contemporary times as it is now. The methodology of writing articles using the type of library research approach through descriptive analysis approach. The results of this study indicate the midpoint of the meeting as a moderate attitude in responding to the phenomenon of the use of Hermeneutics in the interpretation of the Koran. sometimes this Hermeneutic understanding is used while still paying attention to the etiquette of the sacredness of the Qur'an and sometimes it is not used at all in areas beyond the reach of human reason.
\end{abstract}

Keywords: Hermeneutics; Interpretation; The Glory of the Qur'an 


\section{Pendahuluan}

Sesungguhnya agama Islam telah sempurna, nyata, terang lagi jelas, tidak ada yang menyimpang darinya kecuali pasti binasa. Dan Islam, adalah agama yang berlandaskan wahyu Allah SWT, bukan berlandaskan akal fikiran maupun perasaan manusia. Barang siapa mengikuti wahyu, maka sesungguhnya ia berada di atas jalan yang lurus. Allah Tabaraka wa Tảala berfirman:

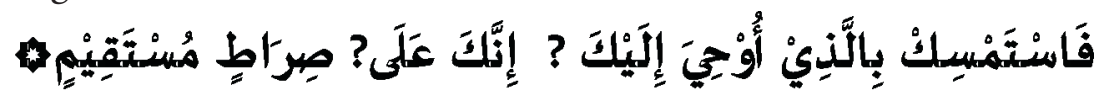

"Maka berpegang teguhlah kepada yang telah diwahyukan kepadamu. Sesungguhnya kamu berada di atas jalan yang lurus". [QS. az-Zukhruf/43:43].

Wahyu Allah merupakan kebenaran mutlak, tidak ada kedustaan dan kesalahan di dalamnya. Hal ini berbeda dengan akal dan fikiran manusia yang tidak ada jaminan kebenaran mutlak, bahkan fikiran seseorang itu sering berubah-ubah. Demikian juga fikiran manusia yang satu dengan lainnya, juga sering berbeda. Oleh karena itulah manusia itu sering berselisih. Allah berfirman tentang kebenaran mutlak pada wahyu-Nya:

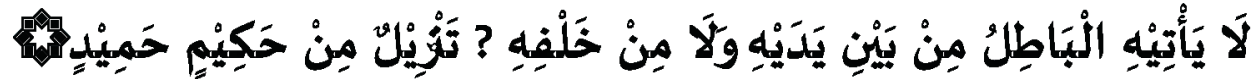

"Kebatilan tidak datang kepadanya (Al-Qur'ân) baik dari depan maupun dari belakangnya. (Al-Qur’ ân) diturunkan dari (Rabb) Yang Maha Bijaksana lagi Maha Terpuji”. [QS. Fushshilat/41:42].

Dalam ayat ini, (Katsir, 2000) menafsirkan bahwa Allah menegaskan bahwa didalam Alquran tidak terkandung kebatilan, baik saat diturunkan maupun sesudahnya. Ibnu Katsier menjelaskan maksud ayat ini adalah Alquran itu tidak memberikan kesempatan bagi kebatilan untuk bertindak leluasa terhadap agama ini. Memahami Alquran dengan baik dan benar merupakan kunci keselamatan seorang hamba dalam memahami dan mengamalkan Islam. Alquran tidak bisa dipahami dengan hanya mengandalkan akal manusia belaka karena Alquran itu kitab wahyu bukan buatan manusia. Metode yang telah diajarkan oleh generasi terbaik ummat ini dalam menafsirkan Alquran adalah dengan metode Tafsir bil Matsur. Metode Tafsir bil Matsur merupakan konsep ilmu tafsir yang banyak ditempuh oleh orang-orang yang dimuliakan Allah azza wajalla. Metode ini sebaik-baik konsep ilmu tafsir, yaitu: menafsirkan Alquran dengan Alquran, menafsirkan Alquran dengan as-Sunnah, menafsirkan Alquran dengan perkataan 
shohabat Rasul, dan menafsirkan Alquran dengan perkataan tabi'in menurut mayoritas pendapat ulama.

Adapun menafsirkan Alquran berdasarkan akal (pendapat) belaka tanpa didasari ilmu yang benar maka ini hukumnya haram berdasarkan apa yang diriwayatkan oleh (Ath Thabari, 2000) dari jalur Ibnu Abbas radhiallahu anhu bahwa Rasulullah $S A W$ bersabda: "Barangsiapa yang mengatakan tentang Alquran dengan pendapatnya atau dengan yang tidak ia ketahui maka tempat baginya adalah Neraka”. Sedangkan (Musa'id bin Sulaiman ath Thayar, 1999)menyimpulkan bahwa menafsirkan Alquran dengan pendapat yang berdasarkan Ilmu dan sesuai dengan kaidah-kaidah ilmu tafsir maka ini diperbolehkan, konsep ilmu tafsir ini dikenal dengan istilah Tafsir bil Ro'yi al-Mahmud. Dalam hal ini interaksi manusia terhadap Alquran, mengerucut pada tiga golongan manusia yakni :

a. Golongan manusia yang masa bodoh, tidak ada keinginan untuk mengkaji, mempelajari bahkan mendalami keagungan Alquran. Mereka inilah golongan manusia yang ingkar kepada Allah dan kebenaran Alquran.

b. Golongan manusia yang memiliki perhatian kepada Alquran, mengkajinya sesuai dengan penjelasan para ulama dan mencukupkan dengan hal itu. Mayoritas pengikut golongan ini adalah kaum muslimin pada umumnya termasuk dalam bagian ini juga pengikut paham normativism.

c. Golongan manusia yang memiliki perhatian tinggi terhadap Alquran tetapi tanpa memperhatikan kaidah dan batasan syariat dalam mengkajinya sehingga terkadang melampaui batasan yang diperbolehkan dan disepakati oleh para Ulama. Termasuk dalam golongan yang terakhir ini adalah para orientalis, Aqlaniyyun dan sejenisnya. Inilah realita ummat manusia dalam berinteraksi dengan Alquran.

\section{Metode}

Tulisan ini merupakan Dalam penelitian ini, penulis menggunakan metode penelitian Deskriptif kualitatif-kritis. Proses penelitian dimulai dengan menyusun asumsi dasar dan aturan berpikir yang akan digunakan dalam penelitian. Asumsi dan aturan berpikir tersebut selanjutnya diterapkan secara sistematis dalam pengumpulan dan pengolahan data untuk memberikan penjelasan dan argumentasi berupa pengumpulan dan penyusunan data, serta analisis dan 
penafsiran data tersebut untuk menjelaskan fenomena dengan aturan berpikir ilmiah yang diterapkan secara sistematis tanpa menggunakan model kuantitatifatau normatif dengan mengadakan klasifikasi, penilaian standar norma, hubungan dan kedudukan suatu unsur dengan unsur lain. (Harahap, 2014). Dalam penjelasannya lebih menekankan pada kekuatan analisis data pada sumber-sumber data yang ada. Sumber-sumber tersebut di peroleh dari berbagai buku dan tulisan-tulisan lainnya dengan mengandalkan teori-teori yang ada untuk diinterpretasikan secara jelas dan mendalam untuk menghasilkan pemahaman yang komprehensif.

\section{Pembahasan}

\section{Alquran, Fungsi, dan Kedudukan}

Dalam akidah Islam Alquran adalah kitabullah yang suci. (Manna' Al Qahthan, 1998) menjelaskan bahwa makna dan huruf Alquran bersumber dari Allah azza wa jalla. Dia Allah táala menurunkan Alquran kepada Rasulullah shalallahu 'alaihi wa sallam melalui perantara malaikat Jibril 'alaihissalam dan menjadikannya sebagai mu'jizat Rosulullah shalallahu 'alaihi wa salam. Oleh karena itu, Mengimani Alquran dengan segala isi kandungannya merupakan kewajiban dan bukti keimanan. Adapun mengingkari Alquran walaupun hanya satu ayat berarti telah menggugurkan keimanan.

Alquran merupakan sumber hukum yang mutlak benar dalam memahami kesempurnaan Islam. Allah menjadikan Alquran sebagai petunjuk bagi hambahamba-Nya dalam menjalani amanah hidup di dunia ini. Kitabullah Alquran ini merupakan nasakh (penghapus) kitab-kitab sebelumnya yang Allah turunkan. Alquran merupakan sumber hukum dalam memahami Islam sudah absolut dan tidak bisa disangkal lagi (QS.5:48). Allah menjelaskan bahwa Alquran itu sebagai Petunjuk (QS. 2: 1-2). (Bukhari, 1999) meriwayatkakn bahwa Umar bin Kaththab Radhiallahu 'Anhu pernah berkata: "Dan inilah kitab (Alquran) yang mana Allah Ta'ala telah memberi petunjuk Rasul kalian maka ambillah niscaya kalian akan diberi petunjuk karena sesungguhnya hanya dengannya Allah memberi petunjuk Rasul-Nya”.

Allah Ta'ala (QS.6 : 155) telah memerintahkan hambaNya untuk mengikuti al Qur'an dan berpegang teguh terhadapnya. Akan tetapi Allah juga menerangkan dalam ayat lain bahwa Alquran ini diturunkan dengan bahasa Arab agar manusia 
berfikir dengan wasilah bahasa yang satu ini sehingga sampai pada esensi tujuan dari wahyu Allah tersebut. Dari paparan diatas, maka jelas ada perbedaan pendapat dalam mengintepretasikan tafsiran ayat-ayat Alquran. Sehingga muncullah model $\mathrm{dn}$ metode penafsiran yang bermacam-macam diantaranya adalah infiltrasi modernisasi Alquran dan metodologi Hermeneutika dalam Studi Alquran yang akan ditemui dalam tulisan ini.

\section{Modernisme Kontemporer Dalam Islam}

Modernisme adalah gerakan yang bertujuan menafsirkan kembali doktrin tradisional, menyesuaikannya dengan aliran-aliran modern dalam filsafat, sejarah, dan ilmu pengetahuan. Modernisme, modernisasi dan modernitas merupakan padanan kata dari pembaharuan. Menurut masyarakat Barat dalam (Yusran Asmuni, 1998) kata modernisasi itu mengandung pengertian pikiran, ide, aliran, gerakan dan usahan untuk mengubah paham-paham, ada istiadat, dan sebagainnya agar semua itu dapat disesuaikan dengan perkembangan zaman yang ditimbulkan oleh kemajuan ilmu pengetahuan dan teknologi.

Modern berarti terbaru, mutakhir atau sikap dan pola pikir serta tindakan yang sesuai dengan tuntutan zaman. Sedangkan modernisasi adalah suatu proses pergeseran sikap dan mentalitas sebagai warga masyarakat untuk dapat hidup sesuai dengan tuntutan hidup masa kini. Modernisasi atau pembaharuan dalam (Yusran Asmuni, 1998) disebut juga dengan reformasi, yakni membentuk kembali, atau mengadakan perubahan atau perbaikan kepada yang lebih baik. Dalam bahasa Arab, modernisasi atau pembaharuan sering diartikan dengan tajdid (yang memperbaharui), sedangkan pelakunya disebut mujaddid (orang yang melakukan pembaharuan). (Majid, 1987) menjelaskan bahwa modernisasi identik dengan rasionalisasi. Maksudnya adalah proses perombakan pola berpikir dan tata kerja lama yang 'aqliyah (rasional), dan menggantikannya dengan pola berpikir dan tata kerja baru yang 'aqliyah. Yang fungsinya untuk memperoleh daya guna dan efisiensi yang maksimal. Modernisasi dilakukan dengan melakukan penemuan mutakhir oleh manusia dibidang ilmu pengetahuan. Dan pengetahuan itu sendiri merupakan hasil pemahaman manusia terhadap hukum-hukum yang obyektif yang menguasai alam, ideal dan material, sehingga alam ini berjalan sesuai dengan kepastian tertentu dan harmonis. Manusia yang bertindak menurut ilmu pengetahuan (ilmiah), ialah manusia yang bertindak menurut hukum alam yang 
berlaku. Jadi modernisasi itu adalah rasionalisasi yang ditopang oleh dimensidimensi moral, dengan berpijak pada prinsip iman kepada Tuhan Yang Maha Esa.

Apabila ditelusuri dalam catatan sejarah, menurut (Zaraboso, n.d.) sebenarnya gerakan modernisme ini berasal dari Eropa abad pertengahan, banyak versi mengenai penyebab munculnya modernisasi ada yang berpendapat kala itu metodologi saintifis mulai berkembang di Spanyol dan berpandangan bahwa apa yang diajarkan gereja tidaklah benar secara saintifis. Ada pula pendapat bahwa paham yang satu ini muncul sejak renaisance terkait dengan masalah agama. Inilah hal awal yang memicu terjadinya revolusi. . Pandangan dasar kaum modernisme terhadap semua agama adalah "agama dapat berubah-ubah menurut situasi dan kondisi serta tidak permanen dan kebenaran absolut itu tidak ada."

Kaum modernis Yahudi dan Nasrani, berupaya menunjukkan bahwa agama masih relevan dengan manusia. Akhirnya mereka pun membuat inovasi didalam agama agar manusia tetap tertarik dengan agama. Seperti ritual menyanyi di Gereja yang diperkenalkan pada tahun 1900-an. Mereka berupaya menyatakan bahwa ketuhanan (divinitas) dan manusia dapat berasimilasi sebagaimana tercantum di dalam Injil, dan bahwa bagian yang benar didalamnya haruslah tidak ketinggalan zaman (out of date). Mereka juga berpandangan bahwa agama senantiasa berubah seiring dengan perubahan zaman dan tidak ada kebenaran mutlak (absolut) di dalam Bible. Pada zaman tersebutlah, banyak orang Islam yang berinteraksi dan belajar di Eropa. Hal ini menyebabkan mereka harus memilih diantara tiga hal : menerima konsep barat, menolaknya atau mencampurnya (reformasi Islam). Mereka yang menerima cara ketiga ini kemudian disebut sebagai modernis Islam, mengembangkan dan menfokuskan pemikiran mereka di Turki dan Mesir. Di Turki sebab negara ini di bawah pengaruh Inggris, dan di Mesir sebab Al-Azhar merupakan pusat ilmu pengetahuan Islam.

(Fahmy Salim Zubair, 2010) menyatakan bahwa berbagai seminar, workshop dan penerbitan buku hasil kajian dan penelitian yang merupakan paketan modernisasi barat digiatkan secara efektif untuk mengampanyekan betapa mendesaknya pembacaan kritis dan pemaknaan baru teks-teks Alquran dan Sunnah Rasul. Berbagai produk olahan isu-isu pemikiran yang diimpor dari Barat seperti sekularisme, liberalisme, pluralisme agama, dan pengarusutamaan gender telah menjadi menu sajian yang lezat untuk dihidangkan kepada komunitas 
muslim. Sebuah pertanyaan apakah tidak sebaiknya upaya pembacaan dan pemaknaan ulang wacana agama itu diarahkan sebagai pembaharuan metode dakwah Islam dan revitalisasi sarana-sarana pendukungnya di era kontemporer ini, sesuai dengan perkembangan zaman?.

Menurut penulis perlu dipertanyakan kepada para pengusung modernisme ini, sehingga benang merah persinggungan antara konservatifisme dan modernisme bisa terurai dengan jelas. Kita memang sangat memerlukan pemikiran yang segar dan cemerlang untuk mendakwahkan prinsip-prinsip dan pandangan hidup Islam dengan metode yang cocok dengan kemajuan zaman. Jika ini yang terjadi, maka kita dengan senang hati menyambut seruan itu. Namun jika yang terjadi adalah mengkaji ulang bahkan sampai pada taraf mengubah prinsip dan pokok-pokok agama dengan dalih keluar dari kungkungan ideologis nash-nash Alquran dan Sunnah, membatalkan absolutisitas nash Alquran dengan analisa historisitas teks atau relativisme teks, juga di bagian lain ingin melakukan studi kritik literatur dan sejarah seperti yang dipraktekkan kalangan liberal Yahudi dan Kristen atas Bible sejak tiga abad silam, atau bahkan dengan memunculkan pandangan bahwa nash Alquran dan Sunnah telah out of date dan hanya menghalangi proses integrasi umat Islam dengan nilai-nilai globalisasi kontemporer.

Jika benar ini yang terjadi di lapangan pemikiran, maka logika semacam ini ditolak mentah-mentah, baik keseluruhan maupun rinciannya. Terdapat sekian banyak bahaya tersembunyi di balik seruan di atas. Yang penting di antaranya berujung kepada pelumeran dan peluruhan inti dan pokok Dienul Islam serta melarikan diri dari kewajiban-kewajibannya. Padahal salah satu tujuan Islam yang mulia adalah terbentuknya umat yang kokoh kuat dalam setiap segi kehidupannya, terutama dalam bidang pandangan hidup yang pasti, barometer akidah, syariah, dan akhlak yang jelas dan tidak tergerus oleh perubahan zaman yang silih berganti.

\section{Menentukan nasib masa depan hermeneutika}

Sebelum penulis membahas tentang sikap manusia dalam masalah ini. Penulis ingin memaparkan historical munculnya Hermeneutika ini terlebi dahulu.

\section{a. Sejarah dan para pengusung hermeneutika}

(Joseph Bleicher, 1980) mengemukakan bahwa hermeneutika secara 
umum dapat didefinisikan sebagai teori atau filsafat tentang interpretasi

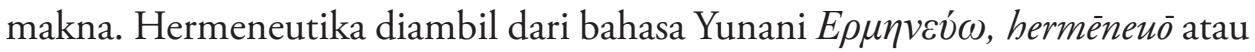
to hermeneutica bentuk jamak dari hermeneuticon yang berarti penerjemahan atau pemahaman suatu pesan. Dalam tradisi Yunani, istilah hermeneutika diasosiasikan dengan Hermes (Hermeios), seorang utusan dewa dalam mitologi Yunani kuno yang bertugas menyampaikan dan menerjemahkan pesan dewa ke dalam bahasa manusia. Menurut mitos itu, Hermes bertugas menafsirkan kehendak dewata (Orakel) dengan bantuan kata-kata manusia.

Dalam The New Encyclopedia Britannica, dikatakan bahwa Hermeneutika adalah studi tentang prinsip-prinsip umum dalam interpretasi Bible (hermeneutics is the study of the general principal of biblical interpretation). (Husaini, 2005) menyebutkan bahwa diantara tujuan dari Hermeneutika adalah untuk menemukan kebenaran dan nilai-nilai dalam Bible. Dalam sejarah interpretasi Bible, ada empat model utama interpretasi Bible, yaitu : literal interpretation, moral interpretation, allegorical interpretation, anagogical interpretation. Dari model-model ini, yang menjadi arus utama sejak awal sejarah Kristen adalah model literal (model Antioch) dan model alegoris (model Alexandria). Keempat model interpretasi Bible tersebut dipraktekkan sejak awal sejarah Kristen (abad ke-4 M), dengan tokohnya Saint Jerome, hingga berakhirnya Abad Pertengahan (abad ke-16 M) dengan tokohnya Marthin Luther. Pada masa modern, Hermeneutika dipelopori oleh Friederich Schleiermacher (1768-1834). Tokoh teolog Protestan ini dikenal sebagai Bapak Hermeneutika Modern yang pertama kali berusaha membakukan Hermeneutika sebagai metode umum interpretasi yang tidak terbatas pada interpretasi kitab suci atau kitab sastra. Kemudian Dilthey (w. 1911) menerapkannya sebagai metode sejarah, lalu Hans-George Gadamer (w.1900) mengembangkannya menjadi filsafat, Paul Ricoeur menjadikannya sebagai metode penafsiran fenomenologis-komprehensif. Selain itu para filosof seperti Jurgen Habermas, Jacques Derrida, dan Michael Foucault, mengembangkan sebentuk kritik Hermeneutika, yaitu analisis atas proses pemahaman manusia yang sering terjebak dalam otoritarianisme, khususnya karena tercampurnya determinasi sosial-budaya-psikologis dalam kegiatan memahami sesuatu. Intinya, ada banyak ragam modernisasi penafsiran ala Hermeneutika ini. Namun menurut (Fahruddin Faiz, 2005), setidaknya ada tiga tipe model 
penafsiran Hermeneutika yang berkembang di tengah masyarakat yakni :

1) Hermeneutika sebagai cara untuk memahami. Contoh tokohnya adalah Schleiermacher, Dilthey, dan Emilio Betti.

2) Hermeneutika sebagai cara untuk memahami suatu pemahaman. Tokohnya semisal Heidegger (w. 1976) dan Gadamer.

3) Hermeneutika sebagai cara untuk mengkritisi pemahaman. Tokohnya semisal Jacques Derrida, Habermas, dan Foucault.

Dalam perspektif pendekatan Hermeneutika, menurut (M. Amin Abdullah, 2004) variabel pemahaman manusia sedikitnya melibatkan tiga unsur. Pertama, unsur pengarang (author). Kedua, unsur teks (text). Ketiga, unsur pembaca (reader). Ketiga elemen pokok inilah yang dalam studi Hermeneutika disebut Triadic Structure. Pada awalnya hemerneutika digunakan oleh mereka yang berhubungan dengan kitab suci (baca Injil) dalam menafsirkan kehendak tuhan kepada manusia. Inilah yang kemudian dikenal dengan ilmu tentang menginterpretasi kitab suci. Akan tetapi tentunya Hermeneutika tidak hanya digunakan sebatas untuk memahami kandungan kitab suci semata, tetapi berbagai disiplin keilmuan. Richard E. Palmer sebagaimana dikutip oleh (Muzairi, 2003) telah memetakan pula Hermeneutika ini sebagai teori penafsiran kitab suci, sebuah metode filologi, ilmu pemahaman linguistic, sebagai pondasi ilmu kemanusiaan, fenomena das sein dan pemahaman eksistensial, serta sistem penafsiran.

Perkembangan selanjutnya, menurut E. Sumaryono (1999) Hemerneutika itu dikenal sebagai proses mengubah sesuatu atau situasi ketidaktahuan menjadi mengerti. Aristoteles pernah menyatakan bahwa kata-kata yang kita ucapkan adalah symbol dari pengalaman mental kita, dan kata-kata yang kita tulis adalah symbol dari kata-kata yang kita ucapkan itu. Sebagaimana terdapat kesamaan bahasa tulisan seseorang dengan yang lain, demikian pula sebaliknya. Akan tetapi pengalaman yang ia simbolkan itu sama seperti yang ada pada kebanyakan orang, sebagaimana imajinasi kita untuk menggambarkan sesuatu.

Dari paparan diatas menjadi jelaslah bahwa Hermeneutika itu berhubungan dengan bahasa. Kita berpikir melalui bahasa, berbicara, dan menulis dengan bahasa. Kita mengerti dan membuat interpretasi dengan 
bahasa. Bahkan semua sisi kehidupan ini tidak terlepas dari bahasa. Sebab itulah keberadaan Hermeneutika tidak terlepas dari pertumbuhan dan kemajuan pemikiran tentang bahasa dalam wacana filsafat dan keilmuan lainnya. Secara epistemis, terbukti bahwa kelahiran tafsir Hermeneutika tidak bisa dilepaskan dari sejarah Yahudi dan Kristen, ketika mereka dihadapkan pada pemalsuan kitab suci, dan monopoli penafsiran kitab suci oleh gereja. Bahkan yang menjadi pemicu pemisahan agama kristen menjadi dua aliran, protestan dan katholik adalah sebab perbedaan penafsiran Bible yang menggunakan metode Hermeneutika.

(M. Amin Abdullah, 2004) menjelaskan bahwa salah seorang yang pertama kali memperkenalkan Hermeneutika dalam penafsiran Alquran adalah Nasr Hamid Abu Zayd (Hermeneutika sastra kritis) yang kemudian menyeru kepada umat Islam agar menafsirkan ulang Alquran agar sesuai dengan tuntutan zaman, akhirnya dia kemudian memperkenalkan Hermeneutika, tapi sayangnya penafsiran yang ia bawa dinilai menyimpang dan tidak sesuai dengan ajaran Islam, bahkan oleh sebahagian ulama ia dianggap kafir. Setelah itu banyak lagi tokoh-tokoh yang mengikuti jejak langkah beliau, sebut saja Hassan Hanafi (Hermeneutika-fenomenologi), Mohammad Arkoun (Hermeneutika-antropologi nalar Islam), Fazlur Rahman (Hermeneutika double movement), Fatima Mernissi, Riffat Hassan, Amina A. Wadud (Hermeneutika gender), Muhammad Syahrur (Hermeneutika linguistik fiqih perempuan).

Dalam diskursus Islam, (M. Amin Abdullah, 2004) juga menerangkan bahwa hemermeneutika merupakan tafsir, takwil, bayan, syarh dan sebutan lainnya. Dalam kajian ushul fiqh cara atau teori memahami atau menafsirkan teks-teks Alquran, hadits atau sumber lainnya dikenal dengan istilah "alistidlal bi al-alfazh". Di kalangan ulama tafsir telah melahirkan tradisi penafsiran Alquran yang luar biasa, yang kemudian dikenal dengan ilmu tafsir. Kecenderungan mereka berkonsentrasi pada pengembangan berbagai kaidah untuk menemukan kandungan teks berdasarkan masa dan tempat turunnya. Dalam analisis tradisional yang lebih menekankan pada aspek lafadz atau teks. Pada perkembangan selanjutnya sistem ini selalu terjaga dan dianggap sebagai sebuah pendekatan yang menghasilkan pemahaman yang benar. Pemahaman ini pada akhirnya dianggap suatu kebenaran yang absolut (despoteisme). Asumsi inilah belakang dianggap sebagai suatu penyelewengan dan tidak 
sesuai dengan logika hukum Islam. Jika demikian, berarti ia telah mengunci teks dalam makna tertentu, berarti itu telah merusak integritas pengarang dan teks tersebut sekaligus. Demikian komentar dari (Abou el-Fadl, 2004), dengan memberikan kesimpulan itu sebagai bentuk kelaliman.

Kajian Hermeneutika memandang bahwa sebuah kalimat, apapun bentuknya, selalu mengandung tiga hal: orang yang menyampaikan atau mengatakannya (mutalaffizh/ mutakallim, pengarang), bahasa itu sendiri (teks/ 'ibarah) dan orang yang diajak bicara, penerima atau pembaca (mutalaqqil sami', pembaca). Inilah prinsip-prinsip yang ada dalam analisis Hermeneutika. Dengan ungkapan lain, (M. Amin Abdullah, 2004) menyatakan bahwa didalam Hermeneutika terdapat tiga unsur yang ikut terlibat di dalamnya, yaitu unsur author (pengarang), unsur teks dan unsur reader (pembaca). Unsur-unsur tersebut memiliki peran dan fungsi masing-masing yang tidak dapat ditinggalkan antara satu dengan lainnya. Bila satu unsur diabaikan dari lainnya, maka yang terjadi adalah penyelewengan dalam pemahaman. Dalam kaitan dengan pembacaan teehadap khazanah keislaman - khususnya Alquran - maka unsur teks itu berarti nash-nash syar'i yakni Alquran dan hadits, unsur pengarang di sini adalah Allah dan Rasululllah, dan unsur pembaca adalah umat Islam.

Hermenutika terbagi ke dalam tiga jenis, yaitu teori Hermeneutika (Hermeneutika theory), filosofi Hermeneutika (Hermeneutika philosophy), dan Hermeneutika kritis. Hermenutika theory memuat aturan metodologis untuk mengantarkan kepada pemahaman yang diinginkan pengarang. Sasarannya ialah untuk meraih makna yang tepat dari teks. Dalam klasifikasi ini, Hermeneutika merupakan acuan yang mengantarkan pada pemahaman yang akurat dan proporsional. Harapannya ialah pemahaman yang komprehensif dengan mempertimbangkan konteks. Makna teks dikaji dari berbagai sisi, baik morfologis, leksiologis, dan sintaksisnya. Keberadaan teks dipertanyakan asal usul, tujuan, dan kondisi yang melingkupi pengarangnya.

Hermeneutika philosophy dalam bukunya (Fahruddin Faiz, 2005) bertujuan untuk menggali asumsi epistemologis dari pemahaman dan lebih jauh lagi ke dalam aspek sejarah, tidak sekadar pada tataran pemahaman teks, tetapi juga pengarang dan dunia pembacanya. Fakus perhatian lebih jauh dari 
jenis Hermeneutika di atas, yakni apa kondisi orang yang memahami teks itu, baik sisi psikologis, sosiologis, historis, filosofis dan lainnya. Kecenderungan ini mengarah kepada epistemologi pemahaman. Sedangkan Hermeneutika kritis merupakan pengembangan dari kedua jenis Hermeneutika di atas meskipun kajian obyek formalnya adalah sama. Letak perbedaannya ialah penekanannya, di mana jenis ketiga ini lebih terfokus kepada determinasideterminasi tersebut memunculkan alienasi, diskriminasi dan hegemoni wacana termasuk di dalamnya penindasan dalam kehidupan sosial-budayapolitik akibat pemaksaan pemahaman oleh kelompok tertentu.

Inilah Hermeneutika sebagaimana disebutkan dalam buku-buku para pengusungnya. Dari paparan diatas, dapat disimpulkan bahwa Hermeneutika murni berasal dari barat, seluruhnya baik dari sisi asal usul, metode, prinsip dan pilar-pilar yang dibangun diatasnya sehingga dengan demikian jelaslah kedudukan Hermeneutika dalam pandangan golongan yang menyerukan dan membela metodologi baru ini. Intinya dari pemaparan di atas, pada dasarnya Hermeneutika merupakan suatu metode penafsiran yang berangkat dari analisis bahasa dan kemudian melangkah ke analisis konteks, untuk kemudian "menarik" makna yang didapat ke dalam ruang dan waktu saat proses pemahaman dan penafsiran tersebut dilakukan. Jika pendekatan Hermeneutika ini dipertemukan dengan kajian Alqur’an, maka persoalan dan tema pokok yang dihadapi adalah bagaimana teks Alqur’an hadir di tengah masyarakat, lalu dipahami, ditafsirkan, diterjemahkan, dan didialogkan dengan dinamika realitas historisnya.

\section{b. Hermeneutika dimata Penentangnya}

Seiring dengan hegemoni peradaban Barat atas Dunia Islam, (Mustaqim \& Syamsuddin, 2002) mengutarakan bahwa Hermeneutika-pun mengalami perkembangan lebih jauh lagi, yakni diaplikasikan oleh para intelektual muslim liberal terhadap Alquran. Pelopornya adalah para modernis (pembaharu) muslim abad ke-19 M sebagaimana disebutkan diatas, seperti Sayyid Ahmad Khan, Ameer Ali, Ghulam Ahmad Parvez, dan Muhammad Abduh. Pada abad ke-20, dalam dekade 60-an hingga 70-an, muncul beberapa tokoh dengan karya-karya Hermeneutika. Hassan Hanafi, Muhammad Arkoun, Fazlur Rahman, dan Nasr Hamid Abu Zayd disebut-sebut sebagai tokoh-tokoh yang 
menafsirkan Alquran dengan metode Hermeneutika.

Freidrich Scheiermacher dianggap sebagai bapak Hermeneutika modern yang juga teolog, mengembangkan Hermeneutika sebagai alat untuk mengkaji al-Kitab dengan karyanya Hermeneutics and Criticism, sebuah karya tentang metodologi kritik teks Perjanjian Baru. Para Sarjana Muslim kemudian menilai kemunculannya ini merupakan sarana untuk menumbuhkembangkan gagasan Barat tentang relativisme dan antikemapanan. Satu hal yang cukup amat penting ilalah bahwa itu sebuah metodologi yang tidak menghormati nilai kesakralan, sebagaimana ketika digunakan untuk membongkar Injil, bukan dari sisi pemahamannya saja akan tetapi terjadi pada teksnya juga.

(Fahruddin Faiz, 2005) menyatakan, ketika asumsi-asumsi Hermeneutika diaplikasikan pada Ulum Alquran, ada tiga variabel yang harus diperhatikan, yaitu teks, konteks, dan kontekstualisasi. Tentang teks, sudah jelas Ulum Alquran telah membahasnya secara detail, misalnya dalam sejarah pembukuan mushaf Alquran dengan metode riwayat. Tentang konteks, ada kajian asbabun nuzul, nasikh mansukh, makki-madani yang katanya menunjukkan perhatian terhadap aspek "konteks" dalam penafsiran Alquran. Tapi, Faiz menyatakan bahwa kesadaran konteks hanya membawa ke masa lalu. Maka menurutnya, harus ditambahkan variabel kontekstualisasi, yaitu menumbuhkan kesadaran akan kekinian dan segala logika serta kondisi yang berkembang di dalamnya. Variabel kontekstualisasi ini adalah perangkat metodologis agar teks yang berasal dari masa lalu dapat dipahami dan bermanfaat bagi masa sekarang. Jika Hermeneutika Alqur'an yang diinginkan sebagaimana diatas maka wajib ditolak berdasarkan beberapa alasan berikut :

1) Hermeneutika Produk Barat

Hermeneutika sebenarnya sejak awal harus dicurigai, karena bukan berasal dari tradisi keilmuan Islam, melainkan dari tradisi keilmuan kafir, yaitu kaum Yahudi dan Kristen, yang digunakan sebagai metode untuk menafsirkan kitab agama mereka (Bible). Allah SWT berfirman (artinya): "Dan apa yang diberikan Rasul kepadamu maka terimalah dia. Dan apa yang dilarangnya bagimu maka tinggalkanlah." (QS Al-Hasyr [59] : 7). Mafhum mukhalafah (pemahaman terbalik) ayat itu, adalah "apa yang diberikan selain Rasul kepadamu, maka janganlah kamu terima dia." (wa 
maa ataakum min ghairi ar-rasuul fa-laa ta'khudzuuhu).

Maka jelaslah disini bahwa Hermeneutika yang tidak datang dari Rasul, haram hukumnya diterima oleh umat Islam. Diriwayatkan bahwa Umar bin Khaththab RA. pernah memegang selembar Taurat. Nabi SAW. melihatnya lalu bersabda, "Tidakkah aku telah mendatangkan sesuatu yang terang benderang bagimu, yang tidak tercemar dan tidak rusak. Andaikata Musa saudaraku menjumpaiku, niscaya dia tidak bisa berbuat apa-apa selain mengikuti aku."

Pendapat ini diperkuat dengan adanya hadits Rasulullah SAW yang secara tekstual menunjukkan hal itu.

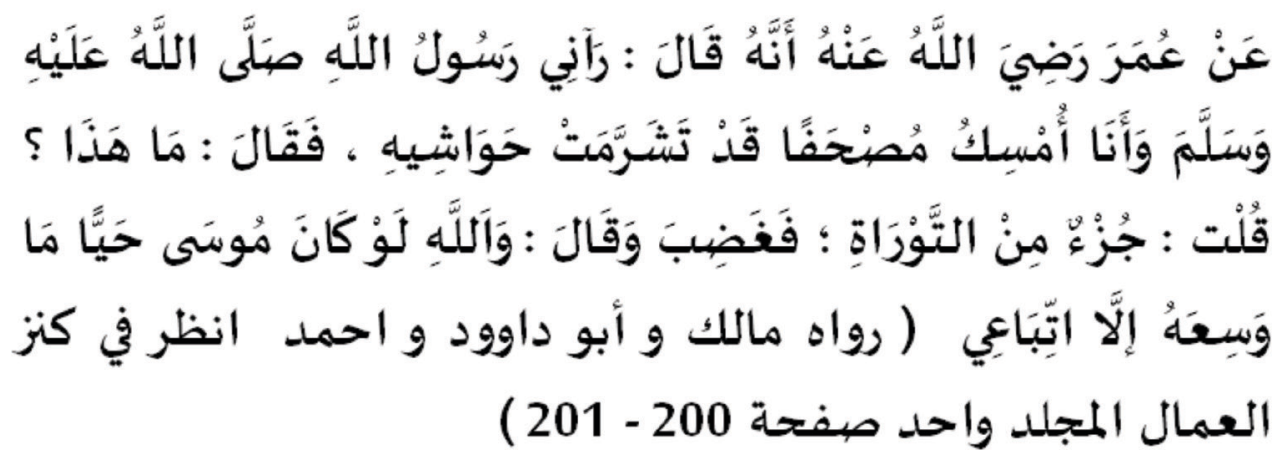

Dalam Riwayat Ahmad, bahkan nabi SAW menegur dengan keras kepada Umar bin Khattab, kata nabi : "Hai Umar apakah kamu kebingungan? Demi Dzat yang jiwaku berada ditanganNya. sungguh aku telah jelaskan islam ini semuanya, terang benderang. Janganlah kamu bertanya sesuatu pun kepada mereka. Sebab bisa jadi mereka mengabarkan yang hak lalu kalian mendustakannya, atau yang batil lalu kalian membenarkannya. Demi Allah, wahai Umar! seandainya Musa masih hidup niscaya dia pun wajib mengikutiku ". (HR. Malik, Abu Dawud dan Ahmad). Pembahasan lengkap hadits ini bisa dilihat pada (Hindi, 2008).

Jika lembaran-lembaran Taurat saja ditolak oleh Islam, maka lebih-lebih lagi (min baabi aula) metodologi tafsirnya alias Hermeneutika. Namun sebagai catatan, Islam membolehkan ummatnya mengadopsi sesuatu dari orang kafir selama tidak mengandung muatan pandangan hidup asing (value-free), seperti sains dan teknologi. Di sinilah makna sabda Nabi Muhammad SAW ; "Antum allamu bi-umuuri dunyaakum” (Kamu lebih tahu urusan-urusan duniamu) (HR Muslim).

Adapun segala ide atau benda yang mengandung muatan 
pandangan hidup asing (value-bond/value-laden), seperti Hermeneutika ini maka Islam tidak dapat menerimanya. Hal ini karena hermeneutika itu bukan termasuk sains dan teknologi yang bersifat universal, melainkan termasuk dalam peradaban (hadharah) yang sarat dengan nilai-nilai kehidupan kufur yang bertentangan dengan Islam.

2) Hermeneutika kurang tepat untuk menafsirkan Alquran

Hermeneutika memang cocok (compatible) jika digunakan untuk menjadi acuan dalam menafisrkan Bible yang usianya sudah beribu abad yang lalu dan sudah kehilangan nilai orisinalitasnya juga banyak masalah, seperti kontradiksi ayat-ayat Bible dengan ilmu pengetahuan.

Hermeneutika dapat diumpamakan tongkat untuk orang buta (cacat). Itu memang cocok dan sudah seharusnya demikian. Contoh, dalam Mazmur (Pasal) 93 ayat 1 tertulis, "Yea, the world is established, it shall never be moved'. Ayat ini menerangkan bumi tidak bergerak, yakni sebagai pusat tata surya (geosentris). Ayat ini secara literal bertentangan dengan temuan Copernicus dan Galileo yang menteorikan matahari sebagai pusat tata surya (heliosentris). Di sinilah Hermeneutika diperlukan untuk menafsirkan ayat tadi secara allegoris (kiasan), bukan dalam makna literalnya yang jelas akan menimbulkan kekacauan pemahaman atau bahkan kegoncangan iman Kristiani. Jadi, Hermeneutika ini mungkin memang cocok untuk Bible, seperti halnya kebutuhan orang buta akan tongkat penuntunnya.Tapi tongkat tidaklah diperlukan untuk orang yang matanya sehat. Sehingga Alquran sangat tidak memerlukan Hermeneutika. Karena Alquran masih terjaga orisinalitasnya, dan tidak mengalami masalah-masalah seperti yang dialami Bible. Allah SWT berfirman menegaskan hal itu di dalam surat al-Hijr ayat 9, bahwa Dialah yang menjamin keutuhan dan keamanan Alquran. Jadi menerapkan Hermeneutika untuk menginterpretasikan Alquran, adalah tidak cocok (incompatible).

Menurut Wan Mohd. Nur Wan Daud dalam (Husaini, 2005), menyebutkan bahwa Hermeneutika teks-teks agama Barat bermula dari masalah-masalah besar, yaitu : (1) ketidakyakinan tentang kesahihan teksteks tersebut oleh para ahli dalam bidang itu sejak awal karena tidak adanya bukti materiil teks-teks yang paling awal, (2) tidak adanya laporan-laporan 
tentang tafsiran yang dapat diterima umum, yakni ketiadaan tradisi mutawatir dan ijma', (3) tidak adanya sekelompok manusia yang menghafal teks-teks yang telah hilang itu. Ketiga masalah besar yang dialami Bible ini, tidak dialami oleh Alquran.

Sesuatu yang mengerikan adalah, ada sebagian pemikir liberal yang kemudian mencoba membuktikan bahwa Alquran juga bermasalah, sebagaimana Bible. Tujuannya supaya penggunaan Hermeneutika menemukan alasannya yang rasional. Mereka menggugat otentisitas teks Alquran yang disebut-sebut sebagai hasil dari hegemoni Quraisy, yang katanya bermotifkan politik belaka. Jelas ini sikap taklid yang berbahaya. Ini dapat diumpamakan seperti orang yang sebenarnya bermata sehat, tapi ingin memakai tongkat untuk orang buta, supaya keren dan terlihat hebat. Akhirnya orang itu pergi ke rumah sakit untuk membutakan matanya, agar punya alasan kuat untuk memakai tongkat orang buta.

3) Hermeneutika menguatkan sekularisme

Dalam praktiknya untuk menafsirkan Alquran, Hermeneutika justru mengokohkan sesuatu yang seharusnya dihancurkan umat Islam, yakni hegemoni sekularisme-liberalisme di Dunia Islam. (Anas, 2010) Sebagai contoh kasus yang terjadi tahun 2004 mengenai draft CLD KHI (Counter Legal Draft Kompilasi Hukum Islam) yang digagas oleh Siti Musdah Mulia. Draft tersebut telah menghasilkan beberapa pasal berbahaya dan kontroversial. Misalnya, mengharamkan poligami (pasal 3 ayat 2), menyamakan bagian waris laki-laki dan perempuan (pasal 8 ayat 3), menghalalkan perkawinan dalam waktu tertentu alias membolehkan kawin kontrak (pasal 28), menghalalkan perkawinan antar agama secara bebas (pasal 54), dan sebagainya. Pasal-pasal ini lahir karena metodologi yang digunakan untuk memahami Alquran adalah Hermeneutika.

Dengan Hermeneutika, ayat-ayat Alquran ditundukkan pada sejumlah prinsip yang sekaligus merupakan pokok-pokok ide sekularisme. Menurut para penggagas CLD KHI, sejumlah ide yang menjadi paradigma draft itu adalah : (1) kesetaraan gender, (2) pluralisme, (3) hak asasi manusia, dan (4) demokrasi. Dari sini jelaslah pola kerja Hermeneutika dalam memperlakukan ayat Alquran di satu sisi, dengan ideologi Barat 
di sisi lain. Modus Hermeneutika ini tidak lain dan tidak bukan adalah menyesuaikan Alquran dengan ideologi Barat, atau praktik ideologi Barat dalam realitas. Ibaratnya, Alquran sekedar makmum, sementara imamnya adalah ideologi kapitalisme-sekular. Apapun gerakan dan doa sang imam, makmum wajib mengikutinya dengan seksama, tanpa menyelisihinya apalagi mendahuluinya. Inilah bentuk shalat jamaah yang bid'ah dhalalah dan munkar yang menjadi pola kerja khas Hermeneutika. Kemungkaran keji inilah yang sering mereka sebut sebagai kontekstualisasi Alquran untuk menyesatkan umat Islam. Hasil kesimpulan akhir uraian diatas adalah dari aplikasi Hermeneutika terhadap Alquran tentu saja bukan untuk kepentingan umat Islam apalagi untuk meninggikan agama Islam. Hasil akhirnya adalah justru untuk menyesatkan umat Islam, menghancurkan agama Islam, dan mengokohkan dominasi sekularisme di dunia Islam.

\section{Korelasi Studi Alquran Dan Hermeneutika Bila Ditinjau Melalui Pendekatan Sastra, Sejarah Dan Sains}

Berdasarkan beberapa uraian di atas, dapat dipahami bahwa Hermeneutika itu tidak lain adalah suatu metode pemahaman, metode memahami suatu pemahaman yang didasarkan pada beberapa langkah dan ciri khasnya, sebagai sarana untuk menguak kandungan teks tertentu, termasuk teks Alquran. Di dalam menyikapi dua kutub umat Islam yang berkomentar tentang Hermeneutika sebenarnya terdapat beberapa cacatan yang dapat diambil, yakni :

a. Memang benar jika Hermeneutika itu merupakan produk Barat dan digunakan sebagai alat tafsir dalam memahami Bibel, akan tetapi tentunya tidak serta-merta harus dicemooh atau dinilai kafir bagi penggunanya, karena bagaimanapun ia hanya sebatas sarana pemahaman tanpa variabel yang baku. Sementara jika Hermeneutika diaplikasikan pada Ulum Alqur`an, harus ada tiga variabel yang harus diperhatikan, yaitu teks, konteks, dan kontekstualisasi. Tentang teks, dalam istilah Ulum Alqur'an telah dibahas secara detail, misalnya dalam sejarah pembukuan mushaf Alqur`an dengan metode riwayat. Tentang konteks, ada kajian asbabun nuzul, nasikh mansukh, makki-madani yang katanya menunjukkan perhatian terhadap aspek konteks dalam penafsiran Alqur`an. Dan di sinilah perlu ditambahkan variabel kontekstualisasi, yaitu menumbuhkan kesadaran akan kekinian dan segala 
logika serta kondisi yang berkembang di dalamnya. Variabel kontekstualisasi ini adalah perangkat metodologis agar teks yang berasal dari masa lalu dapat dipahami dan bermanfaat bagi masa sekarang.

b. Bagi pengguna Hermeneutika perlu menyadari bahwa Alquran merupakan suatu Kitab suci yang memiliki nilai sakral ilahiyah yang perlu dijaga. Prinsip Hermeneutika yang mempertanyakan keorisinalitasan Alquran karena ada ayat dinilai berpihak pada otoritas tertentu, sehingga perlu direduksi - seperti halnya Injil - maka itu perlu ditinjau kembali. Sebab Alqur’an masih terjaga orisinalitasnya, dan tidak mengalami masalah-masalah seperti yang dialami Bible.

Pada hakikatnya Hermeneutika berbeda dengan, tafsir dan ta'wil. Secara singkat definisi ta'wil dapat kita rujuk kepada (Ali Al Jurjani, n.d.) dalam At Tárifat menyatakan bahwa ta'wil adalah mengalihkan lafazh dari maknanya yang zhahir kepada makna lain (batin) yang terkandung di dalamnya, selama makna yang dipilih sejalan dengan Alquran dan Sunnah. Jadi, ta'wil dapat berarti pendalaman makna (intensification of meaning) dari tafsir. (Ar Raghib Al Ashfahany, 2009) dalam Mufradat-nya mengemukakan bahwa tafsir lebih umum daripada ta'wil dan lebih banyak penggunaannya dalam lafaz dan mufradatnya. Tảwîl berfungsi dalam memahami makna-makna dan susunan kalimat serta lebih banyak digunakan dalam kitab suci, berbeda dengan tafsir yang juga digunakan dalam kitab-kitab lainnya. Tanpa memasuki rincian definisi kedua istilah tersebut serta perbedaannya, kita dapat menyimpulkan bahwa keduanya yakni tafsir dan takwil -dalam konteks Alquran- jelas digunakan sebagai alat/cara untuk memahami kata, kalimat dan pesan-pesan Allah.

Ta’wil berbeda dengan Hermeneutika, karena táwilharus berdasarkan dengan tafsir, dan tafsir berdiri di atas lafazh harfiah Alquran. Perbedaan yang lain, orientasi ta'wil adalah penetapan makna, sedangkan orientasi Hermeneutika adalah pemahaman yang berubah-ubah dan nisbi mengikuti pergerakan manusianya. Selain itu, dari latar belakang historisnya, metode Hermeneutika lahir dari rahim tradisi barat yang memiliki sejumlah masalah dengan teks-teks kitab suci mereka. Tanpa disadari kita mungkin belum faham tujuan Hermeneutika, sehingga tidak sadar akan bahayanya jika diterapkan untuk Al Qur'an. Membaca dan memahami kitab suci dengan cara menundukkannya dalam ruang sejarah, bahasa dan budaya 
yang terbatas, adalah watak dasar Hermeneutika yang dikembangkan oleh peradaban barat sekuler yang tidak sejalan dengan konsep tafsir atau ta'wil dalam khazanah Islam.

Bibel yang dibedah dengan metode Hermeneutika, berbeda dengan Alquran yang dipahami maksud ayat-ayatnya dengan ilmu tafsir (interpreter). Masingmasing berbeda sesuai dengan perbedaan metodenya. Bibel menghadapi kritik sejarah dan kandungannya yang dinilai bertolak belakang serta sulit diselesaikan. Penulisannya pun terjadi jauh sesudah kepergian Nabi Isa AS dan bukti-bukti tentang ketidakaslian-nya telah banyak terungkap. Kondisi yang berbeda kita dapati dalam Alquran. Alquran tidak mengalami permasalahan dari segi sejarah. Jika Perjanjian Lama (Bible) sebelum ditulis hanya bersandar pada transmisi oral yang tak jelas riwayat juga sanadnya, Alquran telah dihafal oleh puluhan sahabat di bawah bimbingan Rasulullah SAW. Selain itu Alquran telah ditulis sejak turunnya dan terkodifikasikan dengan baik di masa khalifah Utsman bin Affan RA. Dari segi pewahyuan, Alquran sendiri telah menjelaskan bahwa peran Nabi Muhammad SAW dalam proses pewahyuan adalah pasif dan hanya menerima wahyu tanpa merubah redaksinya sedikit pun.

Cara Hermeneutika memang berbeda dengan cara penafsiran pada umumnya yaitu menafsirkan suatu ayat tidaklah dilihat dari teksnya melainkan juga kontekstual, historis, penulis serta kondisi sosial psikologis sang penulis ketika menulis. Tafsir Hermeneutika pada zhahirnya terlihat menakjubkan dan itu merupakan inovasi baru dalam menafsirkan nash-nash Alquran, tapi pada hakikatnya metode Hermeneutika sangat berbahaya. Ketika kita menafsirkan teks sejarah dengan Hermeneutika itu tidak masalah bahkan bagus karena teks sejarah merupakan swakarya dan karangan sang penulis, tapi ketika kita menafsirkan Alquran dengan Hermeneutika maka itu merupakan kesalahan yang sangat besar karena Alquran bukanlah karangan manusia. Alquran bukanlah buatan Nabi Muhammad SAW sebagaimana dituduh oleh para orientalis dan bukanlah produk budaya sebagaimana yang dikatakan orang-orang liberal. Tetapi merupakan kalam ilahi dan sangat tidak mungkin untuk mengetahui kondisi sosial Sang Khaliq ketika berfirman, karena itu rahasia Allah SAW dan pengetahuan kita terbatas.

Yang perlu digaris bawahi bahwa menafsirkan Alquran merupakan hal yang sensitif, dan kita harus berhati-hati dalam menafsirkannya karena Alquran adalah 
kalamullah sebagai sumber utama hukum Islam. Untuk menafsirkan Alquran ada kaidah-kaidah serta ketentuan yang harus kita penuhi seperti kemampuan berbahasa arab (nahwu sharaf, balaghoh dll), mengetahui asbabun nuzul, tanasubul ayat, dan sebagainya. Perlu diketahui juga bahwa cara-cara penafsiran yang dilakukan oleh salafus shaleh adalah penafsiran yang mempunyai silsilah sanad dalam arti mempunyai sanad sampai ke Rasulullah SAW, berbeda dengan Hermeneutika.

Pada akhirnya terlihat jelas bahwa Hermeneutika yang dimaksud oleh aliran modernisme Islam adalah metode penafsiran yang tidak mau terikat dengan berbagai persyaratan dan metode yang telah menjadi kesepakatan para ulama terdahulu (salaf). Mereka hendak menafsirkan Alquran menurut akal serta hawa nafsu semata. Mereka tidak peduli dengan perkataan Abu Bakar Ash-Shiddieq tentang bahaya menafsirkan Alquran dengan akal murni. Kata beliau, "Langit mana yang akan menaungiku dan bumi mana yang akan kuinjak, andai kata aku menafsirkan Alquran dengan akalku?" Artinya, para ulama dahulu sepakat bahwa jika menafsirkan Alquran hanya dengan akal, walaupun tafsirnya mungkin benar, tetap dihitung sebagai sebuah kesalahan.

\section{Simpulan}

Setelah ditelusuri, dapat disiempulkan bahwa Hermeneutika adalah filsafat pemahaman teks ala barat yang menjadi alat penghapus paling efektif di belakang upaya sekularisasi dan liberalisasi pemahaman Alquran yang terjadi secara massif hari ini. Hermeneutika merupakan suatu pola pemahaman teks dari hasil pemikiran manusia. Suatu sarana untuk sampai kepada makna yang terkandung di dalam suatu teks dengan beberapa langkah dan tekniknya. Meskipun dinilai sebagai produk Barat akan tetapi tidak mesti dinafikan, karena dalam Islam dituntut mengembangkan kreatifitas pemikiran manusia. Di tangan para pengasong sekularisme dan liberalisme, metode Hermeneutika untuk mengkaji Alquran ini ingin menggusur dan mengooptasi ajaran-ajaran Islam yang baku dan permanen (tsawabit), agar sesuai dengan pandangan hidup (worldview) dan nilai-nilai modernitas barat sekuler yang ingin disemaikan ke tengah-tengah umat Islam.

Dewasa ini tidak jarang dengan membawa bendera atas nama Hermeneutika 
lahir penafsiran-penafsiran baru lagi aneh yang dimunculkan oleh mereka yang belum memiliki persyaratan sebagai mufassir bahkan pemahaman tentang Hermeneutika itu sendiri. Alquran turun dengan teks yang jelas dan dekat dengan wilayah kognitif manusia, ditambah lagi dengan pengawalan seorang Rasul yang memberi penjelasan terhadap ayat-ayatnya, maka tanpa harus menggunakan metodologi yang asing dari dirinya, Alquran tetap dapat dipahami dengan jelas maksudnya. Intinya, dalam kaitan metodologi studi Alquran melalui metode penafsiran Hermeneutika menurut penulis bukanlah metode compatible untuk menghasilkan penafsiran kontekstual terhadap Alquran, apalagi jika mempertimbangkan latar belakang Hermeneutika yang lahir dari sebuah semangat untuk mengaktualkan sebuah teks yang jauh dari wilayah kognitif manusia. Maka bagi siapa yang ingin melakukan pendalaman teks-teks Alquran, dengan metode penafsiran Hermeneutika tetap harus waspadai dan berhati-hati sebab akan bermunculan penafsiran berbeda-beda dan kemungkinan besar akan menjauh keluar dari batasan-batasan syar'i. Memang ada pepatah mengatakan: "likulli maqal maqam wa li kulli maqam maqal". Kesadaran akan kemukjizatan dan keorisinalitasan Alquran juga harus tetap dijunjung tinggi.

\section{Daftar Pustaka}

Abou el-Fadl, K. M. (2004). Atas Nama Tuhan, Pent. R. Cecep Lukman Yasin. Jakarta: Serambi Ilmu Semesta.

Ali Al Jurjani. (n.d.). Müjam At Tárifat. Mesir: Darul Fadhilah.

Anas, A. (2010). Konsep Mahar dalam "Counter Legal Draft” Kompilasi Hukum Islam (CLD KHI). Retrieved from http://repository.uinjkt.ac.id/dspace/ bitstream/ 123456789/3399/1/AZWAR ANAS-FSH.pdf.

Ar Raghib Al Ashfahany. (2009). Mufradat Alfaazhul Quran. (S. A. Dawudi, Ed.). Kuwait: Darul Qalam.

Ath Thabari, A. I. (2000). Al Jami' Al Bayan fi Tafsiril Quran.

Bukhari, I. (1999). Shahih Bukhari. KSA: Darus Salaam.

Fahmy Salim Zubair. (2010). Kritik terhadap Studi Al-Quran Kaum Liberal. Jakarta: Gema Insani Press. 
Fahruddin Faiz. (2005). Hermeneutika Alquran; Tema-tema Kontroversial. Yogyakarta: eLSAQ.

Harahap, N. (2014). PENELITIAN KEPUSTAKAAN Oleh: Jurnal Iqra', 08(01), 68-73.

Hindi, A. M. al. (2008). Kanzul Ummal. Beirut: Maktabah Ar Risalah.

Husaini, A. (2005). Wajah Peradaban BArat dari Dominasi Kristen ke Dominasi Sekuler-Liberal. Jakarta: Gema Insani Press.

Joseph Bleicher. (1980). Contemporary Hermeneutics. London: Routledge and Keagan Paul.

Katsir, I. (2000). Tafsir Alquran Al-Azhim. KSA: Dar Ibn Hazm.

M. Amin Abdullah. (2004). "Pendekatan Hermeneutika dalam Studi Fatwa-fatwa Keagamaan” dalam Kholed M. Abou el-Fadl,. In Atas Nama Tuhan, Pent. R. Cecep Lukman Yasin. Jakarta: Serambi Ilmu Semesta.

Majid, N. (1987). Islam Kemoderenan dan Keindonesiaan. Bandung: Mizan Pustaka.

Manna' Al Qahthan. (1998). Mabahits Fi Ulumul Qur'an. Beirut: Mu'asasah arRisalah.

Musa'id bin Sulaiman ath Thayar. (1999). Fushulun Fie Ushulut Tafsir. KSA: Dar Ibnul Jauzi.

Mustaqim, A., \& Syamsuddin, S. (2002). Studi Alquran Kontemporer Wacana Baru Berbagai Metodologi Tafsir. Yogyakarta: Tiara Wacana Yogya.

Muzairi. (2003). Hermeneutika Dalam Pemikiran Islam. In Hermeneutika Alquran Madzhab Yogya. Yogyakarta: Islamika.

Yusran Asmuni. (1998). Pengantar Studi Pemikiran dan Gerakan Pembaharuan Dalam Dunia Islam. Jakarta: Rajawali Grafindo.

Zaraboso, J. (n.d.). Modernisme in Islam.

http : www.Islamweb.net/hadeeth.

http://www.kamusbesar.com/26077/modernisme. 